\section{Letrônica}

\title{
O romance histórico no Brasil: um breve panorama da produção ficcional
}

\section{Historical novel in Brazil: a brief overview fictional production}

Cleia da Rocha Sumiya ${ }^{1}$

Doutoranda em estudos literários da Universidade Federal do Paraná, na linha Literatura, história e crítica. E integrante do
grupo de pesquisas "Estudo sobre fiç̧ão

E-mail: cleiadarocha@hotmail.com
RESUMO: Este trabalho propõe fazer um breve panorama do romance histórico brasileiro na contemporaneidade. Partindo dos conceitos teóricos de Lukács, somado aos apontamentos de outros teóricos contemporâneos, busca-se verificar a configuração dessa forma literária a partir da década de 90, auge dessa produção entre nós, até a produção atual (2015). Pretendemos demonstrar que embora a forma tenha sofrido uma série de mudanças, ainda continua sendo uma tendência forte nos dias atuais.

PALAVRAS-CHAVE: Romance histórico; Percurso teórico; Literatura contemporânea.

ABSTRACT: This paper proposes to make a brief overview of the Brazilian historical novel in contemporary times. Starting from the theoretical concepts of Lukacs, added to the notes of other contemporary theorists, we seek to verify the configuration of this literary form from the 90 s, the height of this production among us, to the current production (2015). We intend to demonstrate that although the form has undergone a number of changes, still remains a strong trend today.

KEYWORDS: Historical novel; Theoretical path; Brazilian contemporary literature. 


\section{Introdução}

tualmente, o campo dos estudos literários se abre para pensar as relações Aentre a literatura e outros discursos tais como: a história, a sociologia, a filosofia, o cinema, as artes plástica. É irrefutável que esta aproximação não é recente, principalmente com o discurso histórico e sociológico, mas, aparentemente, hoje ela se faz com mais autonomia, já que as fronteiras que dividiam essas áreas parecem estar menos nítidas.

Neste sentido um dos gêneros que mais trabalha este caráter híbrido seria o romance histórico. A própria junção dos termos romance, como sinônimo de ficção e histórico, como sinônimo de verdade, contribuem para esta qualidade de interdiscurso.

Na contemporaneidade muitas polêmicas cercam o termo romance histórico, principalmente com relação à permanência da forma pensada por Lukács, no século XIX, em um momento em que o próprio discurso histórico passa por uma série de transformações. Neste sentido, muitos críticos optam por chamar a essa forma herdeira de Lukács de ficção histórica, metaficção histórica ou novo romance histórico. Em nosso trabalho usaremos os termos ficção histórica e romance histórico como sinônimos. Isso não significa dizer que nos referimos ao segundo termo estritamente no sentido lukasiano. Entendemos o adjetivo histórico associado ao gênero romance como uma característica mais ampla que envolve e aceita as próprias mudanças do que se convencionou chamar de discurso histórico.

Para György Lukács o romance histórico nasce e morre no século XIX, pois o surgimento do romance realista burguês impossibilitaria a continuidade desse gênero. Como veremos esta é uma afirmação problemática, uma vez que muitas narrativas enfocando o passado histórico foram escritas após o Realismo. Desta forma, o objetivo de nosso artigo será entender em que medida o decreto de Lukács é válido para as narrativas que enfocam o passado histórico produzidas no Brasil no século XX e XXI. Seria o caso de pensar, como afirmam alguns teóricos (Jameson, Menton, Hutcheon), que estamos diante de uma forma mutante do romance histórico definido por Lukács? Neste sentido, buscamos responder à questão proposta por Jameson (2012) em recente evento sobre o tema: "O romance histórico ainda é possível?".

De pronto já esclarecemos que, enquanto leitores de ficção, e à parte toda essa discussão crítica, na contemporaneidade os autores continuam escrevendo romances que dialogam com história do passado, ainda que muitos neguem de forma veemente a alcunha de romance histórico para suas obras. Conforme já salientou o crítico Perry Anderson (2006) nunca se deixou de se escrever romances históricos, a maioria de qualidade duvidosa, desde Scott.

Como aponta Linda Hutcheon (1991) o fenômeno do revisionismo histórico é tão evidente na contemporaneidade que toda a fiç̧ão da chamada pós-modernidade poderia ser considerada metaficção historiográfica.

No caso do Brasil esse fenômeno se evidencia a partir da década de 90 do século XX e se deve, em parte, à tentativa de resgatar os episódios da história nacional, motivados pelas comemorações dos 500 anos. Conforme aponta Marilene Weinhardt (2011, p. 36): "A contagem por ano permite detectar adensamento das publicações no final da década de 80 e altíssima incidência nos anos iniciais de 90".

Na década seguinte, que concidentemente também é primeira do novo século, há uma diminuição do número de romances e a tematização também sofre uma mudança, embora as fórmulas de ficcionalizar o passado histórico consagradas no século anterior continuem rendendo seus frutos. 0 exemplo mais claro disso é a ficcionalização de autores e personagens literários e escritores. (WEINHARDT, 2010). Também entra em cena um elemento novo que é o resgate da história via discurso de memória, ou melhor, do discurso que simula a memória. 
Para concretizar a proposta de nosso trabalho de tentar entender as dimensões que o romance histórico atinge na contemporaneidade, partindo da década de 90, auge dessa forma literária no Brasil, e chegando aos dias atuais, entendemos que é necessário pensar o percurso do tema também em termos teórico-críticos.

\section{Romance histórico: percurso histórico}

György Lukács em seu ensaio Romance histórico - publicado em 1937, e principal referência aos estudiosos do tema - situa o nascimento do romance histórico no início do século XIX, a partir das narrativas do escocês Walter Scott. Para o teórico as obras de Walter Scott seriam as primeiras a destacar de fato o elemento histórico, compreendido por Lukács (2011, p. 33) como: "o fato de a particularidade dos homens ativos derivar da especificidade histórica de seu tempo", ou ainda como melhor definiu Marilene Weinhardt (1994, p. 50) a partir da leitura de Lukács: "a especificidade histórica do tempo da ação condicionando o modo de ser e de agir das personagens".

Assim, o termo romance histórico remete diretamente ao texto e às ideias de György Lukács, sendo que as discussões propostas pelo filósofo têm sido tomadas por muitos como direcionamento teórico-crítica do que seria esta modalidade narrativa que "encena o passado histórico" (WEINHARDT, 2006b, p. 33). O ensaio de Lukács tem uma função descritiva e prescritiva, pois partindo da caracterização do modelo scottiano, considerado romance histórico genuíno, Lukács prescreve quais as características que tornariam um romance histórico, filiando outros autores e obras a essa modalidade, entre os quais destaca a obra Os noivos, de Manzoni e com alguma relutância Guerra e Paz, de Tolstói.

Entre as características apresentadas pelo teórico destacam-se as seguintes: no romance histórico, as particularidades do tempo histórico deveriam direcionar a ação dos personagens, interpenetrando uma relação entre as ações coletivas e individuais. Embora, as grandes figuras históricas empíricas pudessem ser representadas no enredo, a elas não caberia a ação principal, mas sim às camadas intermediárias e baixas da sociedade, ou seja, aos "heróis medianos". A consciência da história, buscada pelo crítico marxista, determinava também que a ação narrada deveria ocorrer num tempo pretérito à vida do autor, num passado distante ao qual o presente se ligaria numa cadeia diacrônica e evolutiva (LUKÁCS, 2011, p. 33).

Para o György Lukács, o romance histórico só seria possível por meio de uma consciência da história coletiva perpassando a história individual, por isso para ele a forma entra em declínio com o Realismo e o Naturalismo, movimentos literários em que se focaliza, respectivamente, o individualismo do mundo burguês, e a tentativa de retratar fielmente a realidade, mesmo que para isso se suprimisse "as forças motrizes essenciais da história" (LUKÁCS, 2011, p. 253). O crítico entende que essas escolas literárias solaparam com a capacidade épica de narrar, colocando o enredo em um eterno presente e diminuindo, portanto, o papel da história nos acontecimentos.

Muitos críticos posteriores afirmaram a importância do trabalho de Lukács, embora discordassem de alguns de seus pontos salutares. Como diz Perry Anderson (2007, p. 205) “Qualquer reflexão sobre a estranha trajetória desta forma deve partir de Lukács, não importa quanto se afaste dele em seguida.".

A afirmação de que o romance histórico teria acabado após a inauguração do realismo burguês, hoje é um dos pressupostos lukasianos mais combatidos entre esses críticos. O romance histórico mudou desde Walter Scott, a ele foram acrescentados alguns novos conceitos, mas ele continuou existindo como prática discursiva. Muitas vezes os críticos entenderam que era preciso dar outro nome à atualização dessa modalidade. Linda Hutcheon (1991, p. 22), importante crítica do tema, chamou de metaficção 
historiográfica a narrativa que autorreflexiva, portanto metaficcional, se apropria de "acontecimentos e personagens do passado". Para Hutcheon não é possível determinar a natureza concreta dos acontecimentos, uma vez que só temos acesso aos vestígios textuais para transformá-los em fatos. Assim a ficção metahistoriográfica questiona a veracidade do discurso histórico e exterioriza sua condição de "construto discursivo".

Seymour Menton (1992) situa o nascimento de um novo subgênero de romance histórico a partir das reflexões dos críticos uruguaios Ángel Rama (1981) e Fernando Ainsa (1988) que contemplam as formas peculiares da narrativa hispanoamericano, chamando atenção para o processo de paródia e sátira da história. Menton, assim como Hutcheon, concluiu que o nome romance histórico não daria conta das novas características da produção hispano-americana, a partir O reino deste mundo (1949) do cubano Alejo Carpentier, marcada pela paródia, dialogismo, intertextualidade, anacronismo, consciência metaficcional, entre outros. Desta forma, conclui que estamos diante de um novo romance histórico, que mais do que apenas uma nova nomenclatura é significativamente uma nova forma de romance cujas características em muito se diferenciam das destacadas por Lukács.

Na esteira dos novos textos basilares sobre essa modalidade narrativa se inscrevem o nome de Fredric Jameson (2007) e o já citado Perry Anderson (2007). Jameson, bastante ligado à teoria de Lukács, no provocativo e sugestivo texto "O romance histórico ainda possível?" destaca que a forma romanesca do século XIX mudou tanto para se adequar aos pressupostos da chamada modernidade que fica difícil afirmar que o que vemos hoje é ainda um tipo de romance histórico. Ao contrário da teoria de Hutcheon, para quem o presente está sempre dialogando com o passado, ainda que seja para desconstruí-lo, Jameson afirma que atualmente vivemos numa espécie de presente continum no qual o olhar para o passado só se dá por necessidade de evasão. Ademais, o público se misturou ao privado, e as catástrofes, guerras, ou seja, aqueles conflitos que provocavam a consciência da história sobre o indivíduo se tornaram tão cotidianas a ponto de alterar totalmente a perspectiva da referência histórica. Deste modo, essas mudanças na relação do homem com a história e o tempo impossibilitariam o romance histórico, que segundo Jameson (2007, p. 185) seria aquela narrativa em que se articularia "uma oposição entre o público ou histórico (definido seja pelos acontecimentos, crises, líderes) e um plano individual, denotado pela categoria que denominamos personagens.". Para ele, na modernidade dissolveu-se esta dualidade de planos que seria "a condição indispensável para a existência do romance histórico" (JAMESON, 2007, p. 202). No entanto, o próprio Jameson, contraditoriamente, termina sua explanação apontando que "no que toca ao romance histórico a necessidade irá produzir mais invenção, de modo que insuspeitadas novas formas do gênero inevitavelmente irão abrir seus caminhos" (JAMESON, 2007, p. 203).

Perry Anderson participou do mesmo evento em que Jameson proferiu a conferência acima citada, e seu texto "Trajetos de uma forma literária" responde às reflexões do crítico. Anderson, assim como Jameson, retoma Lukács, no entanto sua análise segue outra direção. Ao contrário de Jameson, ele acredita que o romance histórico ainda resiste, reinventando suas formas e objetos. Aliás, para Anderson o romance histórico, ou essa "forma literária" como ele prefere chamar, nunca deixou de ser produzido desde o século XIX. Produziu-se um "imenso monte de lixo", sem dúvida, mas ainda assim eram romances históricos. Para o autor o momento atual é muito profícuo para esta forma narrativa, principalmente na América latina, que saindo de um período de ditaduras, sente necessidade de revolver o seu passado traumático.

Para Jameson as tragédias cotidianas impossibilitam o olhar para o passado, Anderson, ao contrário, afirma que é justamente devido a elas que o homem contemporâneo sente a necessidade de entender seu percurso no 
tempo. Ele entende o romance histórico como "forma literária que lida com uma concatenação de acontecimentos públicos no passado", e neste sentido, o romance histórico atual pode ser visto "como uma tentativa desesperada de nos acordar para a história” (ANDERSON, 2007, p. 19) e não uma fuga da história como acredita Jameson.

Entre os críticos brasileiros vários autores vêm pensando a relação entre a história e a ficção como, por exemplo, o crítico Luís Costa Lima, que em várias de suas obras aborda o tema, destaque para o livro História. Ficção. Literatura, publicado em 2007. Pensando, especificamente, na relação entre história e ficção no romance histórico, podemos destacar o trabalho dos os pesquisadores, Antonio Roberto Esteves, da UNESP e Marilene Weinhardt, da UFPR.

As reflexões de Esteves filiam-se aos conceitos de Menton e de seu novo romance histórico, buscando inserir as obras brasileiras no contexto da produção hispano-americana. Marilene Weinhardt apresenta uma visão mais alinhada à concepção de Anderson, dando contribuições originais para pensar principalmente a produção ficcional brasileira de 1981 até os dias atuais.

Buscando efetivar as bases conceituais de sua sistematização Marilene Weinhardt destaca em "O Romance Histórico na Ficção Brasileira Recente" o que entende como ficção histórica:

Partindo do pressuposto que estamos de acordo quanto ao que se denomina ficção, me detenho no adjetivo. Uma resposta mais apressada tende a indicar como histórica aquela ficção que encena o passado. Não é preciso ser filósofo para saber que essa noção é tão vaga que acaba não significando muito se não a cercamos de alguns esclarecimentos. 0 fonema que se acabou de emitir, as noções sobre criação, expostas por Platão, a infância de qualquer um de nós é passado, o dia de ontem ou o minuto que acabou de passar são passados. 0 estudo do passado se chama História, mas nem tudo o que passou é objeto da história, porque nem todo passado é histórico. Os historiadores costumam distinguir acontecimento de fato histórico. Dizendo de maneira redutora, transforma-se em fato histórico aquele acontecimento que é aprendido pelo historiador como significativo para entrar em um encadeamento e explicar seu tempo. Ficção histórica é aquela que ficcionaliza a história (WENHARDT, 2006, p. 134-135).

Observamos que a pesquisadora atualiza a própria diferenciação de Lukács entre o romance histórico e o drama de costumes. Um romance não é histórico porque situa a ação no passado, mas sim porque aquele passado é determinante para a ação coletiva, logo Weinhardt (2006) entende que a base desse subgênero é sua relação com a história de um modo muito específico, de tal forma que reserva tal denominação para o texto ficcional:

[...] em que a historicidade é determinante para o enredo, ou seja, a obra em que a inscrição dos fatos narrados em um determinado tempo passado é decisiva para que eles tenham ocorrido como tal e, de modo explícito ou não, o texto dialoga com o discurso histórico, ou melhor, com discursos históricos (WEINHARDT, 2006, p. 137).

Podemos observar que tendo em vista a concepção acima citada, uma série de obras brasileiras pode ser lida como romances históricos, ainda que se afastem em alguns aspectos da prescrição de Lukács.

\section{Percurso ficcional: obras e autores}

Com relação ao percurso ficcional, no Brasil, das obras que "encenam o passado histórico" (WEINHARDT, 2006b, p. 33) podemos observar que desde o século XIX elas vêm sendo produzidas, ainda que em número reduzido ou restritas a um só autor. José de Alencar, por exemplo, nos romances As minas de prata e A guerra dos mascates recria enredos ficcionais centrados em episódios históricos do Brasil colônia. 
Esse era um subgênero de produção bastante minoritária entre nós até os anos 70 do século XX, quando segundo Baumgarten (2000, p. 170) "assistimos ao aparecimento de um grande número de romances voltado para a recuperação e a escrita da história nacional, que é revisitada em seus diferentes momentos."

Entre as décadas de 70 e 80 do século passado são publicados uma série de romances que focalizam acontecimentos importantes de nossa história oficial, citamos: Galvez, imperador do Acre (1976), de Márcio Souza; A prole do corvo (1978), de Luiz Antonio de Assis Brasil; A estranha nação de Rafael Mendes (1983); de Moacyr Scliar; Viva o povo brasileiro, (1984) de João Ubaldo Ribeiro; Os varões assinalados (1985), de Tabajaras Ruas; $A$ cidade dos padres (1986), de Deonísio da Silva. Em 1981 Silviano Santiago publica Em liberdade (1981), romance-diário em que ficcionaliza a vida de Graciliano Ramos. A obra é marco de uma linha de romances históricos que, em um exercício metaficional, ficcionalizam a própria história da literatura brasileira (WEINHARDT, 2006; BAUMGARTEN, 2000; ESTEVES, 1998; 2008).

Essa produção inicial da década de 70 e 80 alcança um número bastante significativo na década de 90, conforme apontam os críticos Marilene Weinhardt (2006 a) e Antonio Roberto Esteves (2008). Destaque para alguns títulos: Videiras de cristal (1990), de Assis Brasil; Agosto (1990), de Rubem Fonseca; Sonhos tropicais (1993) de Moacyr Scliar; Ana em Veneza (1994), de João Silverio Trevisan; Galantes memórias e admiráveis aventuras do virtuoso conselheiro Gomes (1994), de José Roberto Torero; A última quimera (1995), de Ana Miranda; Rios inumeráveis (1997), de Álvaro Cardoso Gomes; Terra Papagalli (1997), de José Roberto Torero e Marcus Aurelius Pimenta.

Os títulos acima citados são só uma amostra de romances que se aproveitam do passado histórico das mais diversas maneiras, passando pela apropriação do discurso histórico sobre conflitos, guerras, migrações até desembocar na ficcionalização do próprio discurso literário pela retomada de autores e personagens literários.

Entre os autores que mais produziram ficções históricas nesse período, dois nomes se destacam. Trata-se de Luiz Antonio de Assis Brasil e Ana Miranda. 0 primeiro já vinha produzindo romances ambientados em um passado histórico desde a década de 70. Um quarto de légua em quadro (1976) e A prole do corvo (1978), seus dois primeiro romances situam o enredo no século XIX, abordando, respectivamente, a colonização açoriana e a guerra dos farrapos. Na década de 80 , dando continuidade a uma obra que já se deixava se marcar pelas características desse subgênero, Assis Brasil publica o romance Cães da província (1987), também ambientado no século XIX, e cujo enredo circula entre a vida do teatrólogo Qorpo Santo e um crime absurdo ocorrido em Porto Alegre na época.

Na década de maior florescimento do romance histórico brasileiro, Assis Brasil contribui com Videiras de Cristal (1990); Um castelo no pampa - trilogia (1992-1993); Concerto campestre (1997) e Breviário das terras do Brasil (1997), todos ambientadas em um passado constituído historicamente, o que tornam o gaúcho uma referência no gênero da narrativa histórica.

Ana Miranda que estreiara na poesia em 1978, produz em 1989 seu primeiro romance histórico Boca do inferno, no qual ficcionaliza a vida do poeta Gregório de Matos, na Bahia do século XVII. Seu próximo romance $O$ retrato do rei (1990) situa o enredo no século XVIII, focalizando o episódio histórico da guerra das emboabas. Nos anos seguintes, a autora publica na linha da ficção histórica: A última quimera (1995) e Clarice (1996) em que ficcionaliza, respectivamente, a vida de Augusto dos Anjos e Clarice Lispector. Ainda em 1996 publica Desmundo cuja narrativa recria ficcionalmente um episódio empírico do século XVI e Amrik romance sobre a imigração árabe. Por sua proeminente produção ela também se destaca como uma autora cuja matéria ficcional é o passado. 
As obras e autores acima citados são apenas alguns exemplos dessa tendência que é a reatualização de episódios histórico e junto a eles somam-se uma série de autores que também incursionaram pelo subgênero. Alguns aceitam com naturalidade a denominação de seus romances como históricos, outros relutam contra tal classificação. João Silvério Trevisan, por exemplo, em entrevista a Jose Castello no caderno 2 de $O$ Estado de São Paulo, acerca do romance Ana em Veneza (1995) afirma: "Não gosto de romance histórico e não considero que Ana em Veneza seja um romance histórico. Nunca me passou na cabeça escrever um romance histórico" (apud ESTEVES, 2008, p. 54). Mesmo à revelia do autor, Antonio R. Neves (2008) e Marilene Weinhardt (2006a) concordam que essa é uma obra que pode ser lida como ficção histórica, justamente por focalizar a ação no passado e fazer "um painel abrangente da cultura brasileira do século XIX até quase o final do século XX [...]" (WEINHARDT, 2006a, p. 154).

No caso da obra Videiras de cristal, a posição do autor é semelhante à de Trevisan. Na nota explicativa, publicada no final da obra, Assis Brasil afirma:

Sempre persegui a idéia de escrever um romance sobre os muckers, um romance que, com maior ou menor fidelidade aos fatos, narrasse a trajetória pessoal de algumas personagens - reais ou fictícias - que tiveram parte de suas vidas ligadas ao episódio do Ferrabrás. Nunca me passou pela cabeça escrever um romance histórico, muito menos uma 'história romanceada'. Assim, os puristas de plantão devem esquecer o propósito de conferir datas, nomes e eventos; talvez os encontrem subvertidos ou mascarados pela fantasia - não tão feérica - do autor (ASSIS BRASIL, 2002, p. 51).

É interessante destacarmos que, embora alegue que não quer escrever um romance histórico, o autor cita na nota explicativa uma série de documentos históricos acerca da revolta no morro do Ferrabrás, que segundo ele foram consultados para escrever o romance dos Muckers.
Esteves (2008, p. 54), apesar das advertências de Assis Brasil, destaca que Videiras de cristal "segue a seara das narrativas baseadas em episódios históricos" que consagraram o autor gaúcho como "um dos escritores mais importantes da contemporaneidade" e herdeiro literário de um dos mais importantes romancistas a retratar o Rio grande do Sul: Érico Veríssimo. Mais à frente, Esteves argumentará que, apesar dos protestos dos autores (Trevisan e Assis Brasil) contra a classificação de suas obras como romances históricos, essa seria a melhor maneira de denominar "essas obras cuja ação ocorre num passado muito anterior ao tempo do escritor" (ESTEVES, 2008, p. 55).

Esteves pensando nos motivos que levam os autores a negarem a denominação de suas obras como romance histórico argumenta que a negativa ocorre porque esses autores associam o romance histórico "aos parâmetros estabelecidos por Sir Walter Scott, no início do século XIX" (ESTEVES, 2008, p. 56). O curioso, no entanto, é que segundo ele, essas narrativas:

[...] estão permeadas por uma minuciosa reconstituição histórica, tão cheias de detalhes que muitas vezes se aproximam da reconstituição arqueológica comum nos romances do final do século XIX. Por outro lado, elas mantêm um claro diálogo com uma enorme quantidade de textos históricos e literários, num tom altamente paródico e carnavalizado (ESTEVES, 2008, p. 56).

Sem dúvida que a reconstituição histórica é patente em todos os romances do subgênero, uma vez que é ela que garante a verossimilhança e assegura a manutenção do pacto de leitura no qual o leitor acredita que os fatos narrados foram passíveis de ocorrer naquele momento histórico. No entanto, nem todas as obras deixam transparecer o "tom altamente paródico e carnavalizado" com intenção de desconstruir o discurso em que se firmam, no caso o histórico, e ainda alguns romances são claramente mais paródicos 
do que outros. Na seara da década de 90, Terra Papagalli (1997), de José Roberto Torero e Marcus Aurelius Pimenta e Galantes memórias e admiráveis aventuras do virtuoso conselheiro Gomes (1994) de José Roberto Torero, são um exemplo claro dessa vertente mais paródica e "debochada" da ficção histórica.

Em uma contraposição direta entre as obras dos autores de maior referência da década de 90, observamos que os dois autores seguem tendências diferentes ao abordar o passado histórico. Para explicarmos essa apropriação do passado histórico, tomemos como exemplo dois romances já citados: Videiras de cristal (1990), de Assis Brasil e Desmundo (1996), de Ana Miranda.

Com relação a Videiras de cristal, podemos afirmar que concordamos apenas em parte com a ideia de Esteves, acima citada, pois nesta narrativa ainda não conseguimos localizar os elementos do discurso "paródico e carnavalizado". Pelo contrário, é a semelhança com o modelo scottiano que nos faz questionar em que medida o romance histórico formulado por Lukács é realmente uma forma superada na contemporaneidade.

Em Desmundo, por outro lado, notamos que a autora arregimenta mais os elementos da contemporaneidade, especificamente o recurso paródico e polifônico, por isso, talvez grande parte da crítica prefira filiar essa e outras obras da autora à chamada metaficção historiográfica, alinhando-a, portanto, aos conceitos pensados por Linda Hutcheon sobre ficção e história.

Quando pensamos na oposição entre as obras Videiras de cristal e Desmundo fica evidente uma série de diferenças estruturais, mas no que concerne à relação com a história, uma nos parece fundamental: a escolha das personagens principais. Jacobina Maurer de Videiras de cristal, ainda que em condição secundária, é uma personagem empírica envolvida em um conflito do século XIX, tão paradigmático que requereu a ação do próprio exército nacional; Oribela, de Desmundo, por sua vez, trata-se de uma personagem criada no romance, ainda que o evento ao qual sua vida esteja relacionada seja histórico. A vinda das órfãs portuguesas para casarem na colônia, no século XVI, tem seu respaldo em um texto histórico, a carta de 1552 do padre Manoel da Nóbrega enviada ao Rei D. João e cujo fragmento é usado no paratexto do romance de Ana Miranda.

Já escrevi a Vossa Alteza a falta que há de mulheres, com quem os homens casem e vivam em serviço de Nosso Senhor, apartados dos pecados, em que agora vivem, mande Vossa Alteza muitas orphãs, e si não houver muitas, venham de mistura delas e quaesquer, porque são tão desejadas as mulheres brancas cá, que quaesquer farão cá muito bem à terra, e ellas se ganharão, e os homens de cá apartarse-hão do pecado (MIRANDA, 1996, p. 7).

Usando a nomenclatura de T. Parsons, recuperada por Walter Mignolo (1993, p. 125), teríamos que Jacobina Maurer é uma personagem migrante, "pois já aceitávamos sua existência antes que fosse escrito o romance", enquanto que Oribela é uma personagem nativa, pois sua existência nos surge via obra de ficção.

Atentando para este modo de criação de personagens no romance histórico, Marilene Weinhardt (2006b), quando da sua sistematização da ficção brasileira contemporânea, aponta que Videiras de cristal se enquadraria no grupo misticismo e ocupação da terra, ou seja, naquele conjunto de narrações que centram sua ação nos conflitos sociais e religiosos que marcaram a história oficial, e portanto tendo como personagens centrais os envolvidos "reais" de tais situações. Desmundo, por sua vez, se enquadraria no grupo anônimo no registro histórico, ou seja, ficcionalizaria um evento histórico utilizando um personagem anônimo de cuja existência não temos prova. A autora alerta que tal classificação não é definitiva, e que muitas obras poderiam enquadrar-se em mais de um tópico. Este é certamente o caso dos dois romances acima destacados.

Sem dúvida que as fronteiras de classificação dos romances são maleáveis, mas pensando, especificamente, no caso das suas personagens principais - 
que são o elemento primordial para se pensar a ação histórica, conforme já vimos por meio das diversas definições de romance histórico - parece que se destacam dois modos de abordar o discurso histórico. Vejamos: ao escolher como personagem central de seu romance, Jacobina Maurer, Assis Brasil nos dirige a um episódio secundário e ao mesmo tempo paradigmático de nossa história oficial: a revolta dos muckers. Conforme o próprio autor destaca, o fato já foi estudado diversas vezes via discurso histórico. Ana Miranda ao recontar a história das órfãs que vêm para o Brasil, dadas em casamento aos nobres locais, certamente não está diante de um evento que age diretamente sobre a história oficial, no entanto pode por meio deste fato secundário relatar o conjunto de mentalidades do Brasil colonial e a figura na mulher nesse espaço.

É interessante notarmos que tanto na teoria do romance histórico de Lukács quanto na de Metaficção historiográfica de Hutcheon a presença de personagens fictícios vivendo os acontecimentos históricos é um procedimento bastante comum. Em Lukács, esse é um elemento essencial do subgênero, juntamente com a narração em terceira pessoa e o distanciamento temporal.

Ao buscar reconstruir ficcionalmente os episódios históricos, ambos os autores se debruçam sobre fontes documentais, no entanto, o essencial das narrativa, a composição das personagens, por exemplo, é concebido nas lacunas. Conforme aponta Linda Hutcheon:

Os discursos pós-modernos inserem e depois contestam nossas tradicionais garantias de conhecimento, por meio da revelação de suas lacunas ou sinuosidades. Eles não sugerem nenhum acesso privilegiado à realidade.

0 real existe (e existiu), mas nossa compreensão a seu respeito é sempre condicionada pelos discursos, por nossas diferentes maneiras de falar sobre ele (HUTCHEON, 1991, p. 202).

Sem dúvida, os dois romances são recriações de um episódio real do passado condicionado por um discurso de atualização que é em si "sinuoso" e "lacunar", no entanto o romance de Ana Miranda expõe mais sua condição lacunar, por meio de "um deslocamento autoconsciente na direção da forma do próprio ato de escrever" (HUTCHEON, 1991, p. 168) que se dá em função da composição da personagem e das formas de organizar o relato.

Ainda pensando nas diferenças entre os dois romances retomemos Fredric Jameson, no já citado "O romance histórico ainda é possível?", lembrando que ele propõe critérios bem específicos para qualificar um romance como histórico. Segundo ele:

Não (...) apenas a representação de um período de transição histórica, mas também, e em larga medida, a encenação de uma revolução e uma contrarrevolução; em outras palavras, de um daqueles eventos paradigmáticos, como a própria guerra, que sempre devem estar no centro de um romance histórico (...) para que ele se qualifique como tal (JAMESON, 2007, p. 188).

A questão para nós é entender em que termos e proporções Jameson está pensando essa guerra. Explicando melhor: a revolta do ferrabrás passa para a história oficial do Brasil como mais uma revolta mística armada, talvez incapaz de agir além dos limites territoriais de São Leopoldo, mas é um fato que vem a envolver toda a população dessa região e marcá-la para a posterioridade.

Observamos que em Desmundo não há esse evento paradigmático capaz de mudar a estrutura da comunidade. A luta de Oribela é individual e embora seja perpassada por um conjunto de forças históricas, ao final da narrativa não se verifica nenhuma mudança sobre a macro estrutura local. Neste sentido, a ação de Oribela não serve como paradigma senão para ela mesma, ao contrário das ações de Jacobina Maurer que afetam a sociedade que a cerca.

Apesar das diferenças estruturais, tanto em Videiras de cristal como em Desmundo temos "a especificidade histórica do tempo da ação condicionando 
o modo de ser e de agir das personagens" (WEINHARDT, 1994, p. 50), temos, portanto, a qualidade essencial para a narrativa histórica. Conforme destacamos, no primeiro caso a narrativa é menos lacunar e centrado em um evento paradigmático, estando mais alinhada à perspectiva lukasiana, no segundo caso temos uma reconstrução mais lacunar e paródica que expõe seu caráter de metaficção historiográfica.

Como observamos, por meio da análise de Videiras de cristal e Desmundo, a narrativa de vertente histórica da década de 90 é ampla e alinhada a perspectivas distintas, no entanto mantém em comum, a condição de ficção que revisita a história oficial dos séculos anteriores, usando a imaginação para preencher as lacunas deixadas pelas fontes documentais.

No começo do século XXI, o romance histórico sofre uma guinada. Segundo Weinhardt (2012, p. 246) a ficção histórica que "constituiu uma expressiva linha de força da produção brasileira nas derradeiras décadas do século XX" não se manteve no mesmo patamar no novo século, sofrendo um declínio na "atenção da crítica sobre essa modalidade" e também na própria produção de obras.

A crítica, no entanto alerta que embora tenha havido uma diminuição no número de obras desse teor, a ficção que se volta para o passado histórico segue sendo uma tendência expressiva no século XXI.

Neste sentido, destacamos ainda a contribuição da produção de Assis Brasil e Ana Miranda. O primeiro dando continuidade a sua literatura do sul com O Pintor de retratos (2001); A margem imóvel do Rio (2003); Música perdida (2006) e Figura na sombra; a segunda revisitando a historiografia literária por meio de Dias \& Dias (2002) e Semíramis (2014).

A ficcionalização de personagens e autores literários que se apresentava como uma das linhas de força do romance histórico na década de 90 mantém-se firme na primeira década do século XXI, além das obras de Ana Miranda já citadas acima, são exemplos: A filha do escritor (2008), de Gustavo
Bernardo; O Dom do Crime (2010), de Marco Luchesi; Era no tempo do Rei (2007), de Ruy Castro, para situar apenas alguns nomes.

Após 2010, observamos um interesse na ficcionalização do período do Brasil Império e Colônia com a publicação de quatro narrativas enfocando personagens e acontecimentos que vão do século XVIII ao XIX, referimo-nos à Máquina de madeira (2012), de Miguel Sanches Neto; Em breve tudo será mistério e cinzas (2013) de Alberto A. Reis; Quatro soldados (2013), de Samir Machado de Machado, 2012 e O bibliotecário do imperador (2013), de Marco Luchesi.

Um exemplo na contramão da relação entre história e literatura nos é dado pela historiadora Mari Del Priore que têm revisitado a história por meio dos recursos do discurso ficcional. Em 2007, ela lançou $O$ príncipe maldito, um romance de "não ficção", como declarou Eduardo Bueno na apresentação da obra sobre o príncipe Pedro Augusto, neto de D. Pedro II. Recentemente Mary Del Priore mergulha de vez na apropriação literária do discurso histórico com seu romance de estreia Beija-me onde o sol não alcança (2015) no qual constrói o relato ficcional de um triangulo amoroso verídico ocorrido nos oitocentos. Sem dúvida que a historiadora subverte a lógica de até então na qual eram os romancistas que se utilizavam do discurso histórico para compor romances, e é entre nós a primeira historiadora a escrever um romance histórico.

Mary Del Priore aplica na prática o postulado teórico do também historiador Hayden White que em seu livro Meta-história: A imaginação histórica do século XIX discute as estreitas relações entre o trabalho do historiador e do romancista. White considera que o pensamento histórico opera com a representação, portanto não é isento de ficcionalização. Hayden White, assim como Hutcheon entende que o historiador tenta explicar o passado através da busca de rastros, "achados", que se perdem nas crônicas do passado. A diferença entre "história" e "ficção" para muitos se deveria ao 
fato de que o historiador "acha" suas estórias após a pesquisa documental, ao passo que o ficcionista "inventa" as suas. No entanto, ele aponta que a invenção também desempenha um papel importante "nas operações do historiador" (WHITE, 1995, p. 22) de forma, que também a história passaria por um processo de ficcionalização.

Afora o exemplo isolado, mas salutar da historiadora que escreve narrativas ficcionais, um novo elemento é acrescido na relação entre história e literatura no século XXI, esse sim se delineando como uma tendência. Trata-se da narrativa que recupera o passado histórico por meio da memória, ou melhor, por meio da narrativa que ficcionaliza o discurso de memória e que, portanto se atém a um passado histórico mais próximo do presente.

A relação entre memória e história não é recente, o tema já foi abordado tanto pela linha da História quanto pela linha da Filosofia da História, respectivamente em Memória e História de Jacques Le Goff e Memória, história e esquecimento de Paul Ricouer, para citarmos apenas dois exemplos dessa seara teórica. E se a memória é a matriz da história como afirma Ricouer (2007, p. 100), nada mais coerente do que a ficção histórica, principalmente a do passado recente, se debruçar sobre o tema. Neste sentido o discurso memorialístico efetiva-se como uma linha de força na ficção histórica recente. Marilene Weinhardt (2012, p. 247) em recente levantamento sobre os romances que ficcionalizam a relação entre memória história aponta que:

Expressiva parcela, em termos numéricos e particularmente quanto à realização estética, é constituída por discursos em primeira pessoa, figurando a ação de relatar no presente da escrita, ou seja, na contemporaneidade. Os narradores apresentam-se como indivíduos maduros ou mesmo muito idosos, e contam suas próprias vivências, na modalidade memorialística, situando suas ações em conjunção com o momento histórico. Não se tem em vista, nesta seleção, a vertente que se vem denominando autoficção, nem o romance autobiográfico, definido por Philippe Lejeune (WEINHARDT, 2012, p. 247).
A crítica destaca que com relação ao uso do discurso de memórias, em muitos romances o tempo da escrita coincide com o tempo de vida do autor, em outros casos "o tempo do narrador memorialista é situado em faixa que não coincide com o tempo da escrita e do escritor" (WEINHARDT, 2012, p. 247), sendo que nesse caso o discurso memorialístico é apenas um recurso ficcional. No primeiro caso, se tomarmos apenas os pressupostos de Lukács, não teríamos um romance histórico, uma vez que não haveria a distância temporal entre a vida do autor e os fatos narrados. No entanto, quase todas as reflexões recentes sobre ficção histórica entendem que este pressuposto de Lukács é baseado numa concepção de "passado histórico" já superada pelo próprio discurso da história que cada vez mais se volta para o passado recente.

Eric Hobsbawm aponta que há uma "zona de penumbra entre a história e a memória; entre o passado como um registro geral e aberto a um exame mais ou menos isento e o passado como parte lembrada ou experiência de nossas vidas" (HOBSBAWM, 1988, p. 15). Segundo o autor essa zona começa com a tradição ou a memória familiar e se estende até o fim da infância quando reconhecemos que os destinos públicos e privados são inseparáveis e se determinam mutuamente. Este espaço é chamado de "terra de ninguém" porque os fatos vigoram entre a memória individual e coletiva (HOBSBAWM, 1988, p. 15).

Desta forma, Marilene Weinhardt (2012) entende que os romances que ficcionalizam o passado recente via discurso de memória (ou que simulam a memória) trabalhariam na perspectiva dessa "zona de penumbra", citada por Hobsbawm. Neste sentido, a crítica entende que a distancia temporal entre a vida do autor e a narração dos fatos não é uma condição si ne quo non para a conscientização sobre o caráter histórico dos acontecimentos.

Entre os romances situados nessa "zona de penumbra", publicados na primeira década do século XXI; que se utilizam do discurso de memórias; 
tempo narrado predominantemente no século XX; conjugação dos eventos pessoais com os sócio-históricos a autora destaca os seguintes títulos: $O$ fantasma de Buñuel (2004), de Maria José Silveira; Não falei (2004) de Beatriz Bracher; Sob o peso das sombras (2004), de Francisco Dantas; Cinzas do norte (2005), de Milton Hatoum; Antonio (2007), de Beatriz Bracher; Roliúde (2007), de Homero Fonseca; A chave de casa (2007), de Tatiana Salem Levy; Órfãos do Eldorado (2008), de Milton Hatoum; Heranças (2008), de Silviano Santiago; Yuxin: alma (2009), de Ana Miranda; e Leite derramado (2009), de Chico Buarque; Azul-corvo (2010), de Adriana Lisboa.

Marilene Weinhardt alerta que nessa tendência "a listagem é variada" compreendendo tanto autores estreantes, como nomes experientes na produção de ficção histórica. Também variam "os espaços geográficos e sociais, seja quanto à origem dos escritores, seja quanto à cena ficcionalizada" (WEINHARDT, 2012, p. 249). A memória também não é um recurso exclusivo dos narradores velhos, como mostram as narrativas de Tatiana Salem e Adriana Lisboa.

Indo além da premissa de Marilene Weinhardt sobre os romances que se apropriam do discurso da memória para estabelecer o diálogo com o passado histórico, entendemos que poderia ser incorporada a essa vertente outros romances nos quais os narradores não usam do recurso memorialístico, explicitamente, mas os próprios autores se utilizam de dados autobiográficos para constituir a matéria de seus romances, também efetivando um diálogo com a memória histórica. Esses relatos circundam a "zona de penumbra" de fatos que estão no entre espaço da memória e da história.

Os autores desses romances são como o anjo de Benjamim que a partir de suas memórias olham para o passado, tentando entender a dimensão de suas ruínas individuais e coletivas, são exemplos neste sentido $K$. relato de uma busca (2011), de Bernardo Kucinski e O irmão Alemão (2014), de Chico Buarque.
Em ambos os romances, os autores constroem suas ficções a partir das memórias familiares, memórias essas que estão intimamente ligadas à memória histórica. Os romances se voltam para o momento em que reconhecemos que os destinos públicos e privados estão mutuamente ligados, momento em que a memória constitui a história.

K. relato de uma busca trata-se de um conciso romance que por meio da sobreposição de um conjunto de vozes tenta recuperar o percurso de Ana Kucinski, desaparecida durante a ditadura militar, centrando-se na narrativa em $3^{\underline{a}}$ pessoa (do pai de Ana), mas entremeado por relatos em primeira pessoa; $O$ irmão alemão, de Chico Buarque, por meio de uma narração em primeira pessoa, centra-se na descoberta de um irmão alemão, cujas últimas informações referem-se ao período que antecede à $2^{\underline{a}}$ guerra.

A forma de lidar com o elemento temporal nos romances também se aproxima: ambos os fatos narrados estão situados num tempo pretérito com relação à vida de seus autores, no entanto, ao atualizá-los na narrativa os autores escolhem uma abordagem sincrônica que vai construindo o relato linearmente, como se partisse de um passado e desembocasse nos dias atuais, no entanto não é um passado transposto como lembrança, mas como situação vivida. É como se o autor olhasse para os acontecimentos do passado, a partir de um narrador inserido naquele momento, por isso a metáfora do anjo de Benjamim.

No romance de Chico Buarque a ação romanesca inicia-se na juventude da personagem, por volta de 1960 e chega aos dias atuais, mais precisamente, 2013. As ações de K. também iniciam num tempo pretérito, os anos 70, e desembocam num presente próximo.

Nos romances o diálogo com a história se faz por meio da memória dos autores em profunda consonância com a própria memória coletiva, de forma que ambos lidam com "uma concatenação de acontecimentos públicos no passado", pois os acontecimentos traumáticos que tentam recuperar, via 
discurso, são de conhecimento e relevância pública: a ditadura no romance de Kucinski, a Segunda guerra e ditadura, no romance de Chico Buarque. Nos dois romances o enredo está totalmente ligado à história. Uma história que é do passado, que não existe mais, mas que ainda causa dor ou silêncio em seus donos.

\section{Considerações finais: o romance histórico ainda vive}

Conforme procuramos mostrar em nosso pequeno levantamento acerca da ficção histórica, com maior ou menor fidelidade ao modelo lukasiano, diversos autores têm escolhido situar o enredo de suas obras no passado histórico. Como vimos, a produção atual apresenta um recuo em termos numéricos, isso, no entanto, não quer dizer que a forma encontra-se em declínio. Embora atualmente não tenhamos o boom da década de 90, a narrativa que encena o passado histórico ainda provoca interesse nos autores e leitores e se constitui em temática ainda muito relevante para a teoria e crítica literária.

Atualmente, pensar o romance histórico só é possível tendo em vista as rupturas e permanências da forma desde o romance de Walter Scott. De modo que podemos afirmar que o romance histórico, assim como o próprio romance em geral, recria-se constantemente, e embora esteja atrelado aos pressupostos de uma tradição dialoga e assimila bem as inovações do gênero.

Deste modo, a categoria herdada do século XIX hoje encontra novas formas de abordar o discurso histórico, recebendo as incursões teóricas da própria história. Ela desconfia de si mesma e aponta o seu caráter de construção verbal, nas obras metaficcionais que abordam a obra e vida de autores e o estilo de períodos literários; apropria-se de acontecimentos da história recente por meio dos recursos da memória e passa a tecer suas próprias reflexões sobre a permanência destes eventos na história. Dois exemplos salutares destas rupturas são, respectivamente, A Última Quimera, de Ana Miranda, e O Irmão Alemão, de Chico Buarque. Como vimos, muitas vezes a escolha dos autores se dá como permanência de certos atributos, tradicionalmente associado ao romance histórico, como se observa no caso da obra Videiras de Cristal, de Assis Brasil, ou de Os varões assinalados (1985), de Tabajaras Ruas, não obstante a recusa dos autores à filiações como a da vertente do Romance histórico.

Desta forma, depreende-se que a narrativa histórica atual pode tanto manter um íntimo diálogo com a forma scottiana, como nos mostram algumas ficções históricas, como pode negar seus pressupostos, como no caso do romance de memória, no entanto, seja como filiação à proposta de Lukács, seja como negação desta, o objeto da ficção histórica ainda é o mesmo: a relação do homem com a história. $\mathrm{O}$ romance histórico hoje e ontem trabalha com a noção de consciência histórica, que pode ser resumido em todos os romances como aquele momento em que o personagem se dá conta de que muito de seu percurso se deve às forças do contexto histórico em que está inserido.

Nosso trabalho não intenta apontar conclusões definitivas sobre o tema, uma vez que o próprio encontra-se em transformação. Como afirmamos, anteriormente, nosso artigo orientou-se mais no sentido de responder à indagação de Jameson sobre a possibilidade de uma forma moderna que trabalha na intersecção com o discurso histórico sobreviver na pósmodernidade. O panorama aqui apresentado demonstra que a ficção histórica ainda persiste. A variedade de abordagem desenvolvida pelos romancistas mostra o quanto ela é múltipla.

\section{Referências}

ANDERSON, Perry. Trajetos de uma forma literária. Novos Estudos CEBRAP, São Paulo, n. 77 , p. 205-220, mar. 2007. 
ASSIS BRASIL, Luiz Antonio de. Videiras de Cristal. Porto Alegre: L\&PM, 2010.

BAUMGARTEN, Carlos Alexandre. O novo romance histórico brasileiro. In: Via Atlântica, n. 4, out. 2000. Disponível em: <http://www.revistas.usp.br/viaatlantica/article/view/ 49611>. Acesso em: 10 ago. 2015.

COSTA LIMA, Luiz. História. Ficção. Literatura. São Paulo: Companhia das Letras, 2007.

ESTEVES, Antonio R. O novo romance histórico brasileiro. In: ANTUNES, L. Z. (Org.). Estudos de literatura e linguística. Assis, SP: Arte \& Ciência, 1998. p. 123-158.

Considerações sobre o romance histórico (no Brasil, no limiar do século XXI). In: Revista de Literatura, História e Memória, Cascavel, 2008, v. 4, n. 4, p. 54-66. $\overline{2010 .}$.

HUTCHEON, Linda. A poética do pós-modernismo. História, teoria, ficção. Rio e Janeiro: Imago, 1991.

JAMESON, Frédéric. O romance histórico ainda é possível? In: Novos Estudos, CEBRAP, São Paulo, n. 77, p. 185-203, mar. 2007.

LE GOFF, Jacques. Memória e História. Campinas, SP: Editora da UNICAMP, 1990

LUKÁCS, György. O romance histórico. São Paulo: Boitempo, 2011.

MENTON, Seymour. La Nueva Novela Histórica de la América Latina: 1979-1992. México: Fondo de Cultura Económica, 1993.

MIGNOLO, Walter. Lógica das diferenças e politica das semelhanças: da literatura que parece história, antropologia e vice-versa. In: CHIAPPIN, Lígia; AGUIAR, Flávio Wolf de (Org.). Literatura e História na América Latina. São Paulo: Editora da Universidade de São Paulo, 1993. p. 115-161.

MIRANDA, Ana. Desmundo. São Paulo. Companhia das Letras, 1998.

RICOEUR, Paul. A memória, a história, o esquecimento. Campinas, SP: Editora da UNICAMP, 2012.

TREVISAN, J. S. Entrevista. In: CASTELLO, J. Trevisan tira a identidade do exílio. $O$ Estado de São Paulo. Caderno 2. p. D10, 25 jun. 1995.

WEINHARDT, Marilene. A memória ficcionalizada em heranças e leite derramado: rastros, apagamentos e negociações. Revista Matraga, Rio de Janeiro, v. 19, n. 31, jul.-dez. 2012.
Outros palimpsestos: ficção e história - 2001-2010. In: OURIQUE, João Luiz Pereira; CUNHA, João Manuel dos Santos; NEUMANN, Gerson Roberto. Literatura: crítica comparada. Pelotas: Ed. Universitária PREC/UFPEL, 2011a. p. 31-55.

Romance histórico: das origens escocesas ao Brasil finissecular. In: (Org.). Ficção histórica: teoria e crítica. Ponta Grossa: Editora UEPG, 2011b. p. 12-55.

O romance histórico na ficção brasileira recente. In: CORREA, Regina Helena M. A. (Org.). Nem fruta nem flor. Londrina: Humanidades, 2006. p. 131-172.

Ficção histórica contemporânea no Brasil: uma proposta de sistematização. In: Anais do VI Seminário Internacional de História da Literatura. Porto Alegre, PUCRS 2006b. v. 1, p. 1-6.

. WEINHARDT, Marilene. Considerações sobre o romance histórico. Revista Letras, Editora da UFPR, Curitiba, n. 43, p. 49-59, 1994.

WHITE, Hayden. Meta-história: a imaginação histórica do século XIX. São Paulo: Editora da Universidade de São Paulo, 1992.

\section{Lista de romances citados ao longo do artigo}

ALENCAR, José de. As minas de prata (1866). São Paulo: Melhoramentos, [19??]. 3 v.

. A guerra dos mascates (1874). Rio de Janeiro: José Olympio, 1955.

BERNARDO, Gustavo. A filha do escritor. Rio de Janeiro: Agir, 2008.

BRACHER, Beatriz. Antonio. São Paulo: Editora 34, 2007.

Não falei. São Paulo: Editora 34, 2007.

BUARQUE, Chico. Leite derramado. São Paulo: Companhia das Letras, 2009.

. O irmão Alemão. São Paulo: Companhia das Letras, 2014.

Castro Rui. Era no tempo do Rei. Rio de janeiro: Objetiva, 2007.

DANTAS, Francisco. Sob o peso das sombras. São Paulo: Planeta do Brasil, 2004.

FONSECA, Rubem. Agosto. São Paulo: Companhia das Letras, 1990.

FONSECA, Homero. Roliúde. Rio de Janeiro: Record, 2007.

GOMES, Álvaro Cardoso. Rios inumeráveis. Rio de Janeiro: Topbooks, 1997.

HATOUM, Milton. Cinzas do norte. São Paulo: Companhia das Letras, 2005. Órfãos do Eldorado. São Paulo: Companhia das Letras, 2008. 
KUCINSKI, Bernardo. K: relato de uma busca. São Paulo: Expressão Popular, 2011.

LEVY, Tatiana Salem. A chave da casa. Rio de Janeiro: Record, 2007.

LISBOA, Adriana. Azul-corvo. Rio de Janeiro: Rocco, 2010.

LUCCHESI, Marco. O dom do crime. Rio de Janeiro: Record, 2010.

O bibliotecário do imperador. Rio de Janeiro: Biblioteca Azul, 2013.

NETO, Miguel Sanches. Máquina de madeira. São Paulo: Companhia das Letras, 2012.

REIS, Alberto A. Em breve tudo será mistério e cinzas. São Paulo: Companhia das Letras, 2013.

RIBEIRO, João Ubaldo. Viva o povo Brasileiro. Rio de Janeiro: Nova Fronteira, 1984.

RUAS, Tabajara. Os varões assinalados. Porto Alegre: LP\&M Editores, 1985.

SCLIAR, Moacyr. A estranha nação de Rafael Mendes. Porto Alegre: LP\&M Editores, 1983.

Sonhos tropicais. São Paulo: Companhia das Letras, 1993.

SANTIAGO, Silviano. Em liberdade: uma ficção de Silviano Santiago. Rio de Janeiro: Rocco, 1981.

Heranças. Rio de Janeiro: Rocco, 2008.

SILVA, Deonísio da. A cidade dos padres. Rio de Janeiro: Guanabara, 1986.

SILVEIRA, Maria José. O fantasma de Buñuel. São Paulo: Francis, 2004.

SOUZA, Márcio. Galvez imperador do Acre. 13. ed. Rio de Janeiro: Marco Zero, 1985.

TORERO José Roberto de. Galantes memórias e admiráveis aventuras do virtuoso conselheiro Gomes. Rio de Janeiro: Objetiva, 1994.

TORERO, José Roberto; PIMENTA, Marcus Aurelius. Terra Papagalli. Rio de Janeiro: Objetiva, 2000

TREVISAN, João Silvério. Ana em Veneza. Best Seller: São Paulo, 1994.

\section{Obras citadas de Ana Miranda}

MIRAND, Ana. Boca do inferno. São Paulo: Companhia das Letras, 1990.

O retrato do rei. São Paulo: Companhia das Letras, 1990.

A última quimera. São Paulo: Companhia das Letras, 1995.

Clarice. São Paulo: Companhia das Letras, 1996.
Desmundo. São Paulo: Companhia das Letras, 1996.

Amrik. São Paulo: Companhia das Letras, 1999.

Dias \& Dias. São Paulo: Companhia das Letras, 2002.

Yuxin: alma. São Paulo: Companhia das Letras, 2009.

\section{Obras citadas de Assis Brasil}

ASSIS BRASIL, Luiz Antônio de. Um quarto de légua em quadro. Editora Movimento Instituto Estadual do Livro. Porto Alegre, 1976.

A prole do corvo. Porto Alegre: Editora Movimento Instituto Estadual do Livro, 1978

Bacia das almas. Porto Alegre: Mercado aberto, 1981.

. Cães da Província. Porto Alegre: Mercado aberto, 1987.

Videiras de cristal. Porto Alegre: Mercado aberto, 1991.

. Perversas famílias. Porto Alegre: Mercado aberto, 1992. (Um castelo no pampa, 1).. . Pedra da memória. Porto Alegre: Mercado aberto, 1993. (Um castelo no pampa, 2). . Os senhores do século. Porto Alegre: Mercado Aberto, 1994. (Um castelo no pampa, 3).

Breviário das Terras do Brasil. Porto Alegre: L\&PM Editores, 1997.

O pintor de retratos. Porto Alegre: L\&PM Editores, 2001.

A margem imóvel do rio. Porto alegre: L\&PM Editores, 2003.

Música perdida. Porto Alegre: L\&PM Editores, 2006.

Figura na sombra. Porto Alegre: L\&PM Editores, 2012.

\section{Autores estrangeiros citados}

TOLSTOI, Liev. Guerra e Paz (1869). Trad. Rubens Figueiredo. São Paulo: Cosac Naify, 2011. MANZONI, Alessandro. Os noivos. Trad. Luís Leal Ferreira. Petrópolis: Vozes, 1951.

Recebido em $05 / 10 / 2015$

Aceito em 28/01/2016 